\title{
The insecticidal potential of botanical extracts for management of Peach fruit fly, Bactrocera zonata Saunders, 1842 (Diptera: Tephritidae)
}

\author{
Şeftali meyve sineği, Bactrocera zonata Saunders, 1842 (Diptera: Tephritidae) \\ mücadelesinde bitkisel ekstraktların insektisidal potansiyeli \\ Saira KHAN ${ }^{1}$ \\ Raza AHMAD ${ }^{1}$ \\ Mohammad Maroof SHAH ${ }^{1 *}$ \\ Ihsan ul $H_{A Q^{2}}$
}

\section{Summary}

Methanolic extracts of Isodon rugosus Wall. ex Benth (Labiatae), Boenninghausenia albiflora (Hook.) Rchb. ex Meisn. (Rutaceae), Calotropis procera Aiton (Dryand) (Apocynaceae), Daphne mucronata Royle (Thymelaeaceae), Tagetes minuta L. (Asteraceae), Cinnamomum camphora (L.) J. Presl (Lauraceae) and Eucalyptus sideroxylon A. Cunn. ex Woolls (Myrtaceae), grown in lower Himalayan regions of Pakistan were evaluated at $2 \%$ concentration against Peach fruit fly Bactrocera zonata Saunders, 1842 (Diptera: Tephritidae). Tagetes minuta extract showed maximum of $73 \%$ mortality against male fruit flies and in case of female maximum mortality shown by $C$. camphora and $I$. rugosus was only $16.6 \%$. Boenninghausenia albiflora extract had maximum repellence of $44.4 \%$ followed by $42 \%$ by $D$. mucronata extract and the minimum number of flies were settled on these two plant extracts as compared to the others. The lowest number of pupae $3.3 \%$ as collected from guavas treated with $T$. minuta extract; this was significantly lower than the $62.6 \%$ pupae recovered from untreated guavas. The lowest numbers of adults $(0.33 \%)$ were recovered from guavas treated with $T$. minuta extract compared to $45.3 \%$ adults from untreated guavas. The pupae inhibition was highest $(94.6 \%)$ for $T$. minuta extract. Inhibition of adult emergence was highest i.e. $99.2 \%$ for T. minuta extract. Tagetes minuta can be exploited as a potent source of pesticide against fruit fly, B. zonata, due to maximum pesticidal potential as compared to all other plant extracts applied. The results are discussed in relation with potential benefits of incorporating plant based insecticides in integrated pest management strategies against $B$. zonata.

Keywords: Bactrocera zonata, botanical insecticides, insecticidal activity

\section{Özet}

Pakistan'da Himalaya'nın düşük rakımlı bölgelerinde yetişen, Isodon rugosus Wall. ex Benth (Labiatae), Boenninghausenia albiflora (Hook.) Rchb. ex Meisn.(Rutaceae), Calotropis procera Aiton (Dryand) (Apocynaceae), Daphne mucronata Royle (Thymelaeaceae), Tagetes minuta L. (Asteraceae), Cinnamomum camphora (L.) J. Presl (Lauraceae) ve Eucalyptus sideroxylon A. Cunn. ex Woolls (Myrtaceae) bitkilerinin metanolik ekstraktlarının \%2'lik konsantrasyonlarının Şeftali meyve sineği Bactrocera zonata Saunders, 1842 (Diptera: Tephritidae)'ne karşı etkileri değerlendirilmiştir. Tagetes minuta ekstraktı, erkek meyve sineklerine karşı maksimum \%73 ölüm oranı gösterirken, dişilerde en fazla ölüm oranı sadece \%16.6 ile C. camphora ve I. rugosus ekstraktlarından elde edilmiştir. Maksimum uzaklaştırıcı etkiye \%44.4 ile $B$. albiflora, bunu takiben \%42 ile D. mucronata ekstraktları sahip olurken en az sayıda sinek diğerlerine kıyasla bu iki bitki ekstraktında saptanmıştır. En düşük pupa sayısı \%3.3 ile T. minuta ekstraktı uygulanan guava meyvelerinden toplanırken; bu oran uygulama yapılmamış olanlardan elde edilen \%62.6'ık pupa oranına göre önemli derecede düşük olarak değerlendirilmiştir. Erginlerin en düşük sayıları (\%0.33), T. minuta ekstraktı uygulanan guava meyvelerinden elde edilirken, uygulama yapılmamış olanlardan \%45.3 oranında ergin elde edilmiştir. Pupaların engellenmesi oranı, en yüksek (\%94.6) $T$. minuta ekstraktından elde edilmiştir. Erginlerin ortaya çıkışının engellenmesi \%99.2 ile T. minuta ekstraktı için en yüksek olmuştur. Uygulanan diğer bitki ekstraktlarına kıyasla maksimum insektisit potansiyeline sahip olduğu için, $T$. minuta meyve sineği $B$. zonata' ya karşı etkili bir pestisit kaynağı olarak kullanılabilir. Sonuçlar bitki bazlı insektisitlerin $B$. zonata'ya karşı entegre zararlı mücadele stratejilerine dahil edilmesinin potansiyel faydaları ile ilişkili olarak tartışılmıştır.

Anahtar sözcükler: Bactrocera zonata, bitkisel insektisitler, insektisidal aktivitesi

\footnotetext{
${ }^{1}$ Biotechnology Program, COMSATS Institute of Information Technology, University Road, 22060, Abbottabad, Pakistan

${ }^{2}$ Insect Pest Management Program, National Agricultural Research Centre (NARC), Islamabad, Pakistan

* Corresponding author (Sorumlu yazar): mmshah@ciit.net.pk

Received (Alınış): 22.09.2016 Accepted (Kabul ediliş): 08.11.2016 Published Online (Çevrimiçi Yayın Tarihi): 20.12.2016
} 


\section{Introduction}

The Peach fruit fly, Bactrocera zonata Saunders, 1842 (Diptera: Tephritidae), is one of the most economically important insect pests that causes economic loss by damaging fruit and by interfering international horticultural trade (Shehata et al., 2008). It is native to Asia where it causes severe damage to over 50 species of fruit crop. Its most preferred host is guava, in which losses may reach $50 \%$, if effective control measures are not adopted (Awad et al., 2014)

Like many other species in the genus Bactrocera, males of $B$. zonata show strong attraction to a phenylpropanoid compound, methyl eugenol (ME; 1,2-dimethoxy-4-(2-propenyl) benzene), which occurs naturally in many plant species (Tan \& Nishida, 2012). ME is used to monitor and suppress populations of fruit flies by a male lure and kill approach (male annihilation technique; MAT) (Steiner et al., 1970). The MAT relies on attracting males from the field population in devices containing ME and insecticides (Vargas et al., 2010). To suppress female populations in conjunction with MAT, sprays of protein baits containing insecticides (bait application technique; BAT) can also be used. As components of integrated pest management, both MAT and BAT are more efficient when used on an area-wide basis (AW-IMP). In addition to these control measures, farmers routinely apply synthetic insecticides. However, synthetic insecticide application is undesirable because of adverse effects to the environment, poisonous residues in fruit and issues for international trade (El-Aw et al., 2008).

Due to the limitations of each control strategy as a stand-alone technique, it is recommended that an IPM approach be adopted (Vargas et al., 2015). Although MAT and BAT are components of IPM and these are environmentally benign techniques, overuse of baits with synthetic insecticides deposits a huge quantity of insecticides into the environment, so to protect the environment safer insecticides i.e. Spinosad are incorporated into baits. Therefore, exploring plant based insecticides may lead to the discovery of safer insecticides either for direct application or for incorporation into the baits. Plant extracts can potentially be eco-friendly alternatives to synthetic insecticides in IPM of fruit fly populations.

Different plant extracts have been used effectively against a wide range of insect pests (Isman, 2006). Extracts from some plants, e.g. Acorus calamus L., Azadirachta indica A. Juss, Curcuma longa L., Peganum harmala L., Saussurea lappa (Decne.) C. B. Clarke and Valeriana jatamansi Jones, have shown repellence and growth inhibition of $B$. zonata (Akhtar et al., 2004). More recently, Siddiqi et al. (2006) analyzed turmeric plant extracts in solvents such as petroleum ether, acetone and ethanol, and found that acetone extract gave the highest repellence and growth inhibition of $B$. zonata. An advantage of plant based insecticides is that they contain many substances and are capable of showing higher efficacy against target pests. For example, $A$. indica extract shows anti-feeding effects, repellence, toxicity and anti-oviposition effects on the oriental fruit fly, Bactrocera dorsalis Hendel, 1912 and melon fly, Bactrocera cucurbitae Coquillett, 1849 (Shivendra \& Singh, 1998).

The main objective of this study was to evaluate the insecticidal potential of seven plant species for mortality, repellence and oviposition deterrence of $B$. zonata. This was achieved by analyzing the toxic effects of crude methanolic extracts of the plants on $B$. zonata in laboratory bioassays. The selected plants have been long known for their folk or ethnobotanical uses in northern Pakistan. Exploring the scientific base of traditional use in order to transform local knowledge into commercial use was the major and long term goal of this study.

\section{Materials and Methods}

\section{Plant material}

The leaves of Cinnamomum camphora (L.) J. Presl (Lauraceae) and Eucalyptus sideroxylon A. Cunn. ex Woolls (Myrtaceae), and aerial parts of Isodon rugosus Wall. ex Benth (Labiatae), Boenninghausenia albiflora (Hook.) Rchb. ex Meisn. (Rutaceae), Calotropis procera Aiton (Dryand) (Apocynaceae), Daphne mucronata Royle (Thymelaeaceae) and Tagetes minuta L. (Asteraceae) were collected from northern Pakistan $\left(34.1558^{\circ} \mathrm{N}, 73.2194^{\circ} \mathrm{E}\right)$. These plants are commonly grown in Pakistan and their taxonomic identification was done by Dr. Zafar Jamal, Chairman Botany Department, Abbottabad Government College, Pakistan. 


\section{Rearing of fruit fly, Bactrocera zonata}

Pupae of $B$. zonata were collected from the laboratory colony maintained on an artificial larval diet at the Nuclear Institute of Agriculture, Tandojam, Pakistan. Three to $4 \mathrm{~d}$ before eclosion of pupae, the pupae were received at the Insect Pest Management Program, National Agricultural Research Centre Islamabad, Pakistan. After emergence, the flies were kept in $30 \times 30 \times 45 \mathrm{~cm}$ screened cages and maintained at $26 \pm 1^{\circ} \mathrm{C}$ and $60 \pm 5 \% \mathrm{RH}$ with a 10L:14Dh photoperiod, and fed ad libitum with a protein diet containing hydrolyzed yeast (MP Biomedicals Inc.; www.mpbio.com) and sugar in a 1:3 ratio by weight, and water. On the first day of emergence flies were sexed and kept in separated cages having different food regimes. Male and female flies were identified on the basis of morphological characteristics; the female flies have long pointed ovipositor at the end of their abdomen. Female flies were separated into two groups. One group of females was reared on protein diet that contained both yeast and sugar and the other group was reared on sugar only until they were transferred to experimental cages. Females reared on protein diet were used to assess oviposition deterrence and those on sugar only to assess toxicity. The reason for keeping flies deprived of protein was that protein is critical for producing fertile eggs and protein deprived females will show attraction to protein. Therefore, for assessment of toxicity, females were initially maintained on sugar only and switched to a diet containing protein at the onset of their sexual maturity. Males were in one group and reared on protein diet from emergence onwards because males showed strong attraction to methyl eugenol and there was no need to have different food regimes for their attraction purpose.

\section{Preparation of plant extracts}

Plants were dried in the shade for three months. Dried plant material was ground to powder using an electric grinder. Metabolites were extracted by a maceration method using organic solvent methanol at room temperature (Padin et al., 2013). After $2 \mathrm{~d}$ the solvent layer was filtered with Watman No.1 filter paper and the process repeated three times. The filtrate was concentrated using a rotary evaporator at $35^{\circ} \mathrm{C}$ and resulting extracts stored at $4^{\circ} \mathrm{C}$.

\section{Bioassays}

\section{Adult male fruit fly toxicity bioassay}

After $14 \mathrm{~d}$ of emergence $B$. zonata males from large cage were shifted to experimental screened cages $15 \times 15 \times 20 \mathrm{~cm}$ and kept them for $1 \mathrm{~h}$ before bioassay. Laboratory adopted males reached sexual maturity at $14 \mathrm{~d}$. Studies of $B$. zonata male age response to ME have not been undertaken, however, Shelly et al. (2010) reported that many of the ME responsive males are responsive at the beginning of their sexual maturity. Therefore, sexually mature males were selected for toxicity bioassay by mixing plant extracts with ME. For this bioassay, crude methanolic plant extracts were tested against adult male fruit fly. Four mg each of plant extract was mixed with $200 \mu \mathrm{L} \mathrm{ME}$ and $50 \mu \mathrm{L}$ added to single filter papers in three replicate Petri dishes. These Petri dishes (without lids) were then placed in experimental cages having male flies at 10:00 h and removed after $24 \mathrm{~h}$. Thirty males (10 males in each replication) were exposed to each treatment. Three controls were included; ME (a negative control), untreated filter paper (a negative control) and organophosphate synthetic insecticide i.e. 2,2-dichlorovinyl dimethyl phosphate (DDVP; the positive control). In the positive control,4 $4 \mathrm{~L}$ of DDVP was mixed with $200 \mu \mathrm{L}$ of ME. Mortality was observed after 24 and $48 \mathrm{~h}$. 


\section{Adult female fruit fly toxicity bioassay}

From emergence, female flies were provided with sugar only and after $14 \mathrm{~d}$ they were transferred to experimental cages, starved for $8 \mathrm{~h}$ and switched to protein diet. Feeding toxicity bioassay was used to analyze the toxicity of plant extracts by mixing each plant extract into the diet of the flies (Shakunthala \& Thomas, 2001b). For this purpose, each crude methanolic plant extract was mixed at $2 \%$ into the adult diet and placed on filter paper in Petri dishes. Four mg of each plant extract was first dissolved in $200 \mu \mathrm{L}$ of methanol and then mixed with diet containing $2 \mathrm{mg}$ of sugar and $2 \mathrm{mg}$ of hydrolyzed yeast and placed in experimental cages. In each treatment total of 30 flies were exposed in three replicates of 10 flies. Three control treatments were included; methanol only (a negative control), food containing hydrolyzed yeast and sugar (a negative control) and commercial protein bait containing Spinosad (GF 120; positive control). In the positive control, $12 \mathrm{mg}$ of GF 120 was mixed with $90 \mu \mathrm{L}$ of water as recommended by the manufacture. Mortality was observed after 24 and $48 \mathrm{~h}$.

\section{Repellence and oviposition deterrence bioassay}

Fifty each of virgin male and female fruit flies, maintained on protein diet for $14 \mathrm{~d}$, were combined for copulation 90 min before sunset in a $45 \times 45 \times 45 \mathrm{~cm}$ plexiglass screen cage. Fruit fly couples were collected in plastic vials, transferred to separate cages and left to continue copulation. Next morning female flies were transferred to experimental cages and provide a protein diet and water ad libitum. Fifteen flies (five per replicate) were taken for each treatment for evaluation. Next day at 10:00 h, the females were provided access to guava fruit treated with $2 \%$ crude methanolic plant extracts. The fruit used were of uniform size, cold treated at $4^{\circ} \mathrm{C}$ for $22 \mathrm{~d}$ in order to eliminate any larvae from wild flies and kept at room temperature for $24 \mathrm{~h}$ before exposure for oviposition. In each treatment, $60 \mathrm{mg}$ of plant extract was mixed with $3 \mathrm{~mL}$ of methanol. An aliquot of $1 \mathrm{~mL}$ was applied on each guava by pipette while continuously rotating the guava to ensure uniform distribution over the fruit. Three guavas were used for each treatment ( 1 guava per replication). After treatment, the guavas were allowed to dry for $2 \mathrm{~h}$, then exposed to flies for $48 \mathrm{~h}$. For repellence bioassay, settled or repelled females from treated guava in each treatment were counted every $2 \mathrm{~h}$. For oviposition, deterrent effect bioassay, female flies were removed after $48 \mathrm{~h}$ and guavas were placed in sawdust for $15 \mathrm{~d}$ so that larvae could pupate in sawdust. Number of pupae and emerged adults were counted. Two negative control treatments were included; methanol only and untreated guavas.

\section{Data analysis}

Percent repellence was calculated by using the formula (Rehman et al., 2009):

$$
\% \mathrm{R}=[1 / 2(A-B) / A] \times 100
$$

Where $\mathrm{R}$ represents repellence, a represent half of the number of flies settled on both treated and untreated guavas and $B$ represents number of flies settled on treated guava. Differences in mortality, repellence and oviposition deterrence caused by different plant extracts were analyzed by one-way analysis of variance (ANOVA) Complementary pairwise comparisons of means were performed by Tukey's test. All analyses were performed with SPSS version 16. 


\section{Results}

\section{Adult mortality}

Male mortality between treatments was significantly different $(F=5.79, P>0.001)$. Five treatments, DDVP and T. minuta, I. rugosus, E. sideroxylon and $D$. mucronata extracts, gave similar but significantly higher mortality than all other treatments (Table1). Female mortality was significantly higher with GF 120 treatment than all other treatments (Table1).

Table1. Mean percentage mortality of males and females of Bactrocera zonata exposed tomethanolic extracts of different plants in female protein baits and male lures under laboratory conditions

\begin{tabular}{lll}
\hline Pesticide/Plant extracts & Mortality (female) & Mortality (male) \\
\hline GF $120^{*}$ & $100 \% \mathrm{a}$ & - \\
DDVP* $^{*}$ & - & $100 \% \mathrm{a}$ \\
Tagetes minuta & $6.6 \% \mathrm{~b}$ & $73.3 \% \mathrm{a}$ \\
Isodon rugosus & $16.6 \% \mathrm{~b}$ & $53.3 \% \mathrm{a}$ \\
Daphne mucronata & $13.3 \% \mathrm{~b}$ & $50 \% \mathrm{a}$ \\
Eucalyptus sideroxylon & $3.3 \% \mathrm{~b}$ & $50 \% \mathrm{a}$ \\
Calotropis procera & $0 \% \mathrm{~b}$ & $43.3 \% \mathrm{~b}$ \\
Cinnamonum camphora & $16.6 \% \mathrm{~b}$ & $40 \% \mathrm{~b}$ \\
Boenninghausenia albiflora & $10 \% \mathrm{~b}$ & $26.6 \% \mathrm{~b}$ \\
Methanol* & $0 \% \mathrm{~b}$ & - \\
Methyl eugenol & - & $13.3 \% \mathrm{~b}$ \\
Untreated & $0 \% \mathrm{~b}$ & $20 \% \mathrm{~b}$ \\
\hline
\end{tabular}

*GF 120, positive control for female toxicity bioassay; DDVP, positive control for male toxicity bioassay; methanol, negative control for female toxicity bioassay; methyl eugenol, negative control for male toxicity bioassay. Means followed by the same letter within a column are not significantly different (Tukey's test, $\mathrm{P}<0.05$ ).

\section{Effect of treatments on settlement and repellence behavior of females}

Mean number of females settling on untreated guavas was greater than on treated guavas $(F=$ $5.79, P>0.001$ ). The minimum number of females (3.3 of 15) that settled on any treated guavas was on those treated with $D$. mucronata extract, followed by those treated with $B$. albiflora (3.7 of 15), I. rugosus (4 of 15 ) and C. camphora (4.7 of 15) extracts. Both methanol and C. procera extract treated guavas had 5 of 15 females settle. With E. sideroxylon and T. minuta extracts 5.3 and 6.3 of the 15 females settled, which was also less than the 8.3 females that settled on untreated guavas.

In the repellence bioassay, different treatments showed significantly different repellence $(F=3.06$, $P>0.023$ ). Boenninghausenia albiflora, D. mucronata, I. rugosus and C. camphora extracts gave similar but significantly higher repellence than $C$. procera and E. sideroxylon extracts, and methanol. Tagetes minuta extract showed the least repellence, which was similar to that of untreated guavas (Figure1). 


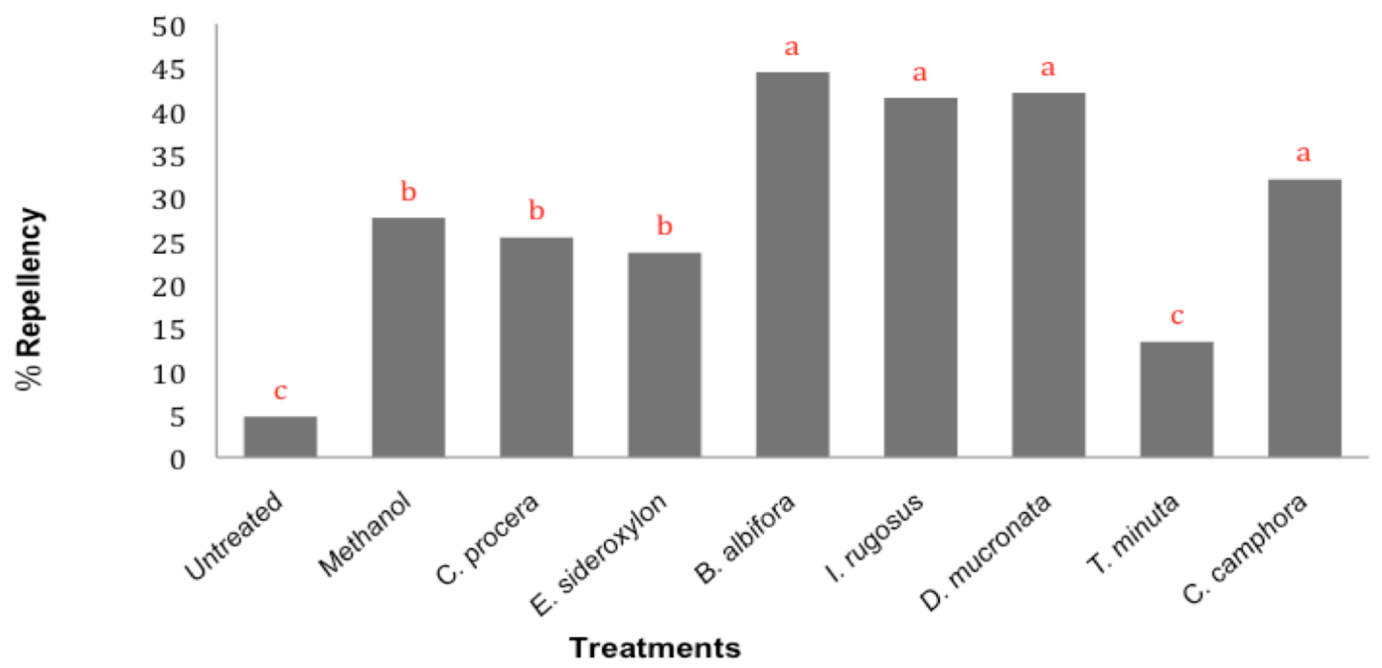

Figure1. Mean percent repellence (\%) caused by selected plant extracts at $2 \%$ concentration against fruit flies, Bactrocera zonata, under laboratory conditions. Means followed by the same letter within a column are not significantly different (Tukey's test, $\mathrm{P}<0.05$ ).

\section{Oviposition deterrence}

\section{Effect of plant extracts on recovery of pupae}

There were significant treatment effects on number of pupae recovered from guavas. ( $F=5.15, P=0.001)$ (Table 2). The lowest number of pupae (3.3) was obtained from guavas treated with $T$. minuta extract, followed by those treated with $D$. mucronata and E. sideroxylon. Treatment with B. albiflora, C. camphora, C. procera and $I$. rugosus extracts resulted in recovery of about 30 to 40 pupae. The highest number of pupae were recovered from untreated guavas.

\section{Effect of plant extracts on adult emergence}

Paralleling the results for pupae, the lowest number of adults emerged was for guavas treated with $T$. minuta extract, followed those treated with $D$. mucronata and $E$. sideroxylon extracts (Table 2).Guavas treated with $B$. albiflora, $C$. camphora, $C$. procera and $I$. rugosus extracts had greater numbers, but the highest number of adults that emerged was for untreated guavas.

Table 2. Mean number of Bactrocera zonata pupae recovered and adults emerging for guava fruit treated with various plant extracts and exposed for oviposition for $48 \mathrm{~h}$

\begin{tabular}{lcc}
\hline Plants Extracts & Pupae Count & Adult Emergence \\
\hline Tagetes minuta & $3.3 \pm 6.16 \mathrm{a}^{*}$ & $0.3 \pm 5.39 \mathrm{a}$ \\
Daphne mucronata & $26.7 \pm 4.55 \mathrm{~b}$ & $7.0 \pm 4.95 \mathrm{a}$ \\
Eucalyptus sideroxylon & $28.3 \pm 4.62 \mathrm{~b}$ & $13.0 \pm 4.71 \mathrm{~b}$ \\
Boenninghausenia albiflora & $31.7 \pm 4.69 \mathrm{c}$ & $13.3 \pm 4.73 \mathrm{~b}$ \\
Cinnamomum camphora & $35.0 \pm 8.38 \mathrm{c}$ & $16.7 \pm 4.44 \mathrm{~b}$ \\
Calotropis procera & $35.7 \pm 9.58 \mathrm{c}$ & $27.3 \pm 3.67 \mathrm{c}$ \\
Isodon rugosus & $39.7 \pm 9.78 \mathrm{c}$ & $29.7 \pm 4.16 \mathrm{c}$ \\
Untreated & $62.70 \mathrm{~d}$ & $45.30 \mathrm{~d}$ \\
\hline
\end{tabular}

*Means followed by the same letters within each column are not significantly different (Tukey's test, $P<0.05$ ). 


\section{Discussion}

The plant species selected for study are common in Pakistan, so are readily available. Apart from $I$. rugosus and $D$. mucronata, the other species have all been reported to have insecticidal effects on a range of insect pests, so this is the first report of the insecticidal potential of $I$. rugosus and $D$. mucronata.

The plant extracts were assayed for their effect as toxicants against $B$. zonata males and females, their repellence effect on females and oviposition deterrence effect. Extracts of $T$. minuta were found to give the highest male mortality and oviposition deterrence, whereas $B$. albiflora extract showed the strongest repellence. Female mortality with these plant extracts was less than for males, which may have been due to differences in the mode of application for males and females. The highest mortality of males with $T$. minuta extract was about $73 \%$ (Table 1), but against females, the highest mortality was only $16 \%$ with $I$. rugosus extract, which was not significantly different from the results with the other plant extracts. The lower mortality in females compared to males may have been due to the plant extracts being mixed into the diet and females may have consumed less toxicants by restricting their intake, whereas the males may have been unable to restrict their intake of plant extracts mixed with ME (Haq et al. 2014).

Currently farmers use synthetic insecticides to control fruit flies. In a summer crop of guava, 5 to 7 insecticide sprays are applied, in mango, 2 to 3 sprays and in plums, peaches, apricot and pear, sprays are applied every 10 to 15 days. Ten percent of total synthetic insecticides applied in Pakistan are for fruit flies (Stonehouse et al., 1998; Siddiqi et al., 2006). Due to unacceptable levels of insecticide residues in fruit and vegetables, exports of these are adversely affected.

As plants contain a rich source of bioactive compounds, they may give an alternative solution to synthetic insecticides for control plant pests and diseases (Ghosh et al., 2012; Pino et al., 2013). According to different reports, plant extracts showed strong pesticidal properties and have additional advantages as these chemicals can be specific for targeted pests, biodegradable to nontoxic products and therefore, considered as appropriate to apply in integrated pest management programs (Tare et al., 2004).

In this study, we assayed the insecticidal effects of different plants by applying extracts in ME and protein baits that ensured the ingestion of these extracts. Among the plant extracts assayed, T. minuta extracts had the highest toxicity for males. The studies of Shivendra \& Singh (1998), Shakunthala \& Thomas (2001a) and Tewari (2001) revealed the insecticidal properties of $A$. calamus and $A$. indica against fruit flies. Assessing the efficacy of neem extracts by applying them along with food, Van Randen \& Roitberg (1998) reported an inverse effect on adult survival and on the development of eggs of Western fruit fly. Van Randen \& Roitberg (1998) also reported that the artificial diet containing neem based insecticides has negative effect on pupae formation and adult emergence of Western fruit fly. Shakunthala \& Thomas (2001b) indicated the significant changes in the appearance of reproductive organs of adult $B$. cucurbitae when the flies were fed with a diet containing $A$. calamus extract. However, the plant extracts assayed in this study did not cause high female mortality. In addition to plant extracts causing mortality of adult fruit flies, they can repel fruit fly females and deter their oviposition. These effects encourage their incorporation in integrated pest management strategies against fruit flies. This study recorded the highest repellence with $B$. albiflora and $D$. mucronata extracts and in was accordance with Walter (1999) and Jimenez et al. (2000), who reported repellence of a number of botanical pesticides against $B$. zonata on guava. Similarly, Singh et al. (2007) reported the repellent effect of neem products as biopesticide against $B$. zonata and $B$. dorsalis. Later studies by Rehman et al. (2009) indicated the effectiveness of petroleum ether, ethanol and acetone extracts of $A$. calamus, Citrullus colocynthis (L.) Schrad., C. longa, $P$. harmala, S. lappa, $V$. jatamansi and for repellence and oviposition deterrence of $B$. zonata and reported promising effects of these plant based pesticides. Solangi et al. (2011) reported that botanical pesticides, such as neem oil, neem seed powder solution, tobacco leaf solution and solution prepared from Eucalyptus leaves, have repellent effects on B. zonata.

Khattak et al. (2006) demonstrated the repellence and growth inhibition caused by petroleum ether, acetone and ethanol extracts of $P$. harmala, S. lappa and Valariana officinalis L. of $B$. zonata. These results are in concurrence with the studies of Akhtar et al. (2004), reporting that three plants, sweet flag, 
neem seed and turmeric rhizomes had repellent effects on $B$. zonata and that turmeric extract had pronounced effect on suppression of egg laying and emergence of pupae and adults. Siddiqi et al. (2006) indicated the pesticidal effect of acetone, petroleum ether and ethanol extracts of turmeric on B. zonata settling response and fecundity, and reported promising results. Studies on foraging and oviposition behavior of different Bactrocera spp. found that these species have a non-resource based mating system (Kuba \& Koyama, 1985; Iwahashi \& Majima, 1986) and adult flies engaged in mating during dusk time at the surrounding vegetation of the main host fruits. This behavior of flies suggests that such control strategies should be useful as an area-wide integrated pest management (AW-IPM) approach. The systemic insecticides are not the preferred choice for fruit flies control in guava fruit and, the insecticides having contact action remained insufficient to give successful control of fruit flies, unless targeting the fruit fly adults in abandoned areas and vegetation. Therefore, plant extract formulations giving oviposition deterrence effects have an added advantage over synthetic insecticides and can be included in integrated pest management programs for the control of fruit flies (Khattak et al., 2006).

\section{Conclusion}

The results of this study demonstrated broad-spectrum toxic effects of the tested plant extracts against $B$. zonata. The noteworthy results are the efficiency of the extracts against fruit fly as toxicants, repellents and oviposition deterrents. These actions can be exploited for the control of $B$. zonata by developing proper delivery strategies. Further investigations are required to separate and identify active compounds present in these active extracts through chromatographic techniques and by different spectroscopic analysis. Such compounds may also have profound effects on hormonal balance and reproductive physiology of other insect pests. This information can be helpful in developing some competent formulations for commercial use against $B$. zonata.

\section{Acknowledgments}

We are thankful to Sayed Muhammad Masoom Shah Rashdi and other colleagues from Nuclear Institute of Agriculture, Tandojam for providing insects for these studies.

\section{References}

Akhtar, N., G. Jilani, R. Mahmood, M. Ashfaque \& J. Iqbal, 2004. Effects of plant derivatives on settling response and fecundity of peach fruit fly Bactrocera zonata (Saunders). Sarhad Journal of Agriculture, 20: 269-274.

Awad, A. A., N. A. Ali \& H. O. Mohamed, 2014. Ultrastructure of the antennal sensillae of male and female peach fruit fly, Bactrocera zonata. Journal of Insect Science, 14 (45): 1-15.

El-Aw, M. A. M, K. A. A. Draz, A. G. Hashem \& I. R. El-Gendy, 2008. Mortality comparison among Spinosad-, Actara-, Malathion-, and Methomyl-containing baits against peach fruit fly, Bactrocera zonata (Saunders) (Diptera: Tephritidae) under laboratory conditions. Journal of Applied Science and Research, 4: 216-223.

Ghosh, A., N. Chowdhury \& G. Chandra, 2012. Plant extracts as potential mosquito larvicides. The Indian Journal of Medical Research,135 (5): 581-598.

Haq, I., Vreysen, M. J. B., Cáceres, C., Shelly, T. E. \& Hendrichs, J., 2014. Methyl eugenol aromatherapy enhances the mating competitiveness of male Bactrocera carambolae Drew \& Hancock (Diptera: Tephritidae). Journal of Insect Physiology, 68: 1-6.

Isman, M. B., 2006. Botanical insecticides, deterrents, and repellents in modern agriculture and an increasingly regulated world. Annual Review of Entomology, 51: 45-66.

Iwahashi, O. \& T. Majima, 1986. Lek formation and male-male competition in the melon fly, Dacus cucurbitae Coquillett (Diptera: Tephritidae), Applied Entomology and Zoology, 21: 70-75.

Jimenez, V. J. A., M. A. Hoy \& F. S. Davies, 2000. Integrated pest management-compatible pesticides for the guava fruit flies Bactrocera zonata. Journal of Economic Entomology, 93: 357-367.

Khattak, M. K., M. F. Shahzad \& G. Jilani, 2006. Effect of different extracts of Harmal, Peganum harmala L. rhizomes of Kuth, Saussurea lappa C. B. Clarke and Balchar, Valariana officianalis L. on the settling and growth of peach fruit fly, Bactrocera zonata Saunders. Pakistan Journal of Entomology, 28 (1): 129-132.

Kuba, H. \& J. Koyama, 1985. Mating behavior of wild melon flies, Dacus cucurbitae Coquillett (Diptera: Tephritidae) in a field cage: Courtship behaviour. Applied Entomology and Zoology, 20: 365-372. 
Padin, S. B., C. Fuse, M. I. Urrutia \& G. M. Dal Bello, 2013. Toxicity and repellency of nine medicinal plants against Tribolium castaneum in stored wheat. Bulletin of Insectology, 66 (1): 45-49.

Pino, O., Y. Sánchez \& M. M. Rojas, 2013. Metabolitos secundarios de origen botánico como una alternativa en el manejo de plagas. I: Antecedentes, enfoques de investigación y tendencias. Revista de Protección Vegetal, 28 (2): 81-94.

Rehman, J., G. Jilani, M. A. Khan, R. Masih \& S. Kanvil, 2009. Repellent and oviposition deterrent effects of indigenous plant extracts to peach fruit fly, Bactrocera zonata Saunders (Diptera: Tephritidae). Pakistan Journal of Zoology, 41: 101-108.

Shakunthala, N. \& J. Thomas, 2001a. Oviposition deterrence of Acorus calamus L. extracts on melon fly, Bactrocera cucurbitae. Journal of Tropical Agricultural Science, 39: 149-151.

Shakunthala, N. \& J. Thomas, 2001b. Evaluation of chemosterilent effect of Acorus calamus L. extracts on melon fly, Bactrocera cucurbitae Coq. Journal of Tropical Agricultural Science, 39: 145-148.

Shehata, N. F., M. W. F. Younes \& Y. A. Mahmoud, 2008. Biological studies on the peach fruit fly, Bactrocera zonata (Saunders) in Egypt. Journal of Applied Science and Research, 4: 1103-1106.

Shelly, T. E., J. Edu \& D. O. Mclnnis, 2010. Pre-release consumption of methyl eugenol increases the mating competitiveness of sterile males of the Oriental fruit fly, Bactrocera dorsalis, in large field enclosures. Journal of Insect Science, 10 (8): 1-16.

Shivendra, S. \& R. P. Singh, 1998. Neem (Azadirachta indica) seed kernel extracts and azadirachtin as oviposition deterrents against the melon fly (Bactrocera cucurbitae) and the oriental fruit fly (Bactrocera dorsalis). Phytoparasitica, 26: 191-197.

Siddiqi, A. R., G. Jilani, J. U. Rehman \& S. Kanvil, 2006. Effect of turmeric extracts on settling response and fecundity of peach fruit fly (Diptera: Tephritidae). Pakistan Journal of Zoology, 38: 131-135.

Singh, M., D. Gupta, R. Gupta \& S. D. Kashyap, 2007. Population dynamics of fruit flies, Bactrocera spp. (Diptera: Tephritidae). Himachal Journal of Agricultural Research, 33 (2): 292-294.

Solangi, B. K., R. Sultana, M. S. Wagan \& N. Ahmed, 2011. Repellent action of botanical pesticides against fruit fly, Bactrocera zonata Saunders in laboratory. Pakistan Journal of Entomology, Karachi, 26 (1): 41-45.

Steiner, L. F., W. G. Hart, E. J. Harris, R. T. Cunningham, K. Ohinata \& D. C. Kamakahi, 1970. Eradication of the oriental fruit fly from the Mariana Islands by the methods of male annihilation and sterile insect release. Journal of Economic Entomology, 63:131-135.

Stonehouse, J. M., J. D. Mumford \& G. Mustafa, 1998. Economic losses to tephritid fruit flies (Diptera: Tephritidae) in Pakistan. Crop Protection, 17 (2): 159-164.

Tan, K. H. \& R. Nishida, 2012. Methyl eugenol: its occurrence, distribution, and role in nature, especially in relation to insect behaviour and pollination. Journal of Insect Science,12 (56): 1-74.

Tare, V., S. Deshpandem \& R. Sharma, 2004. Susceptibility of two different strains of Aedes aegypti (Diptera: Culicidae) to plant oils. Journal of Economic Entomology, 97: 1734-1736.

Tewari, K. K., 2001. Effect of plant extracts spray on fruit fly transmission of cucumber mosaic virus. Journal of Physical Research, 14: 207-208.

Van Randen, E. J \& B. D. Roitberg, 1998. The effect of neem (Azadirachta indica) based insecticides on the survival and development of Juvenile Western cherry fruit fly (Rhagolelis indifferens) (Diptera: Tephritidae), Canadian Entomologist, 130: 869-876.

Vargas, R. I., J. C. Piñero, R. F. Mau, E. B. Jang, L. M. Klungness, D. O. McInnis, E. B. Harris, G. T. Mc Quate, R. C. Bautista \& L. Wong, 2010. Area-wide suppression of the Mediterranean fruit fly, Ceratitis capitata, and the Oriental fruit fly, Bactrocera dorsalis, in Kamuela, Hawaii. Journal of Insect Science, 10 (135): 1-17.

Vargas, R. I., J. C. Piñero \& L. Leblanc, 2015. An overview of pest species of Bactrocera fruit flies (Diptera: Tephritidae) and the integration of biopesticides with other biological approaches for their management with a focus on the pacific region. Insects, 6 (2): 297-318.

Walter, J. F., 1999. "Commercial Experience with Plant Products in Relation to Control Fruit Flies, 155-170". In: Biopesticides: Use and Delivery (Eds. F. R. Hall \& J. J. Menn). Humana Press, Totowa, New Jersey. 